\title{
IMPLEMENTATION OF IN VITRO ASSAY FOR EVALUATION OF BIOCORRECTIVE ACTION OF BIOACTIVE SUBSTANCES AN ANIMAL ORIGIN
}

\section{ИЗУЧЕНИЕ ВОЗМОЖНОСТИ ПРИМЕНЕНИЯ МЕТОДОВ IN VITRО ДЛЯ ОЦЕНКИ БИОКОРРИГИРУЮЩИХ СВОЙСТВ БИОЛОГИЧЕСКИ АКТИВНЫХ ВЕЩЕСТВ ЖИВОТНОГО ПРОИСХОЖДЕНИЯ}

Fedulova L.V., Kashinova E.B., Kotenkova E.A.

The V.M. Gorbatov All-Russian Meat Research Institute, Moscow, Russia

Ключевые слова: aоpma, Sus scrofa, пептиды, биокорригирующее дествие, in vitro, биологическая активность, эксплантат.

\section{Аннотация}

Известно, что продукты убоя являются источником большого количества биологически активных веществ, обладающих различными биологическими эффектами. На настоящий момент выявлено порядка 220 функииональных пептидов, большинство из которых состоят из 2-10 аминокислотных остатков. В данном исследовании изучена биологчческая активность среднемолекулярных (Мм 5-30 кДа) и низкомолекулярных (Мм менее 5 кДа) вешеств, содержащихся в аорте Sus scrofa, с применением методов in vitro. Установлено, что среднемолекулярные и низкомолекулярные фракиии, обладают тканеспецифическим действием на органотипические культуры тканей куриных эмбрионов и лабораторных крыс, при этом наблюдается выраженная зависимость биологической активности от молекулярной массы исследуемых образиов. Показано, что, на эксплантаты аорты куриного эмбриона более выраженное действие оказывают среднемолекулярные фракиии - индекс площади образующегося монослоя клеток составил 56,6 5 5,2 \% (индекс площади монослоя при добавлении низкомолекулярных

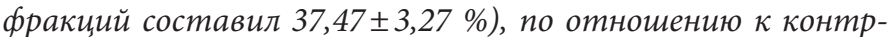
ольным эксплантатам. Низкомолекулярные фракиии оказывали стимулирующее влияние на эксплантаты тканей аорты стареющих крыс - индекс площзади превышал значения среднемолекулярных фракиий более чем на 30\%.

\section{Введение}

Представление о продуктах животноводства, в частности, мясном сырье, как источнике пластичных свойств (белков, жиров, углеводов), претерпело значительные изменения. Последние исследования свидетельствуют о содержании в животных белках значительных количеств аминокислотных последовательностей, обладающих различными биокорригирующими эффектами. Выявлено, что куриный миозин, говяжий коллаген $\alpha 1$, свиной тропонин С обладают широким спектром активностей. Например, говяжий коллаген $\alpha 1$ характеризуется антиамнестическим, антитромботическим, иммуномодулирующим эффектами, регулирует активность слизистой оболочки желудка; куриный миозин - антибактериальной активностью; говяжий коллаген $\alpha 1$ и свиной тропонин С - опиоидными свойствами [1-3]. Показано,
Keywords: aorta, Sus scrofa, peptides, biocorrective action, in vitro, biological activity, explant.

\section{Abstract}

Slaughter products are good source of bioactive substances with different biological effects. Nowadays, approximately 220 functional peptides consisting of 2-10 amino acid residues have been identified. In this study, the biological activity of medium-molecular-weight substances (5-30 kDa, Mw) and low-molecular-weight substances (less than $5 \mathrm{kDa}, \mathrm{Mw}$ ) extracted from aorta of Sus scrofa were investigated in vitro. Medium-molecular-weight and low-molecular-weight fractions possessed a tissue specific effect on organotypic tissue cultures of chicken embryos and laboratory rats. Biological activity depended on molecular weight. Medium-molecular-weight fractions possessed higher effect on aortas explants of chicken embryo: area index of cellular monolayer was $56.6 \pm 5.2 \%$ (area index of the monolayer was $37.47 \pm 3.27 \%$ for low-molecularweight fraction) in comparison with control explants. The low-molecular-weight fractions stimulated aortic tissues explants of aging rats - area index exceeded area index formedium-molecularweight fractions by more than $30 \%$.

\section{Introduction}

Comprehension of livestock products, in particular, meat raw, as a source of essential nutrients (proteins, fats, carbohydrates), was significantly changed. In recent studies animal proteins are claimed as a sourse of amino acid sequences with different biocorrective effects. It was found that chicken myosin, beef collagen $\alpha 1$ and pork troponin $\mathrm{C}$ consisted from a lot of such functional sequences. For example, beef collagen $\alpha 1$ is characterized by antiamnesic, antithrombotic and immunomodulatory effects, regulates the activity of gastric mucosa; chicken myosin — antibacterial activity; beef collagen $\alpha 1$ and pork troponin $\mathrm{C}-$ opioid properties [1-3]. Myosin light chain enriched se- 
что легкая цепь миозина богата последовательностями антимикробного действия, полипептид поперечнополосатых мышц - коннектин - пептидами антитромботической, антиамнестической, опиоидной, нейропротекторной, иммуномодуляторной, антиоксидантной и гипотензивной активностями; говяжий, куриный и свиной актин богаты последовательностями-ингибиторами дипептидилпептидазы IV. Помимо этого, коллаген и эластин содержат последовательности, несущие определенные корригирующие свойства за счет высокого содержания функциональных аминокислот - глицина и пролина [4]. Стоит отметить, что в вышеперечисленных и прочих животных белках на настоящий момент идентифицировано более 220 функциональных пептидов, при этом, большинство из изученных пептидов состоят не более чем из 2-10 аминокислотных остатков. При этом, наиболее изученными на настоящий момент являются гипотензивные пептиды, которые по механизму действия делятся на корректоры эндотелиальных клеток-предшественников, ренин-ангиотензиновой системы за счет снижения концентрации ренина или ингибирования ангиотензин-превращающего фермента (АПФ), а также активаторы NO-синтазы. Наряду с этим, показано, что гипотензивные последовательности высвобождаются при гидролизе миозиновой тяжелой цепи куриного бедра и коллагена, говяжьих саркоплазматических белков, свиного небулина, миозина (тяжелая цепь), актина, тропонина С и титина, говяжьего, свиного и куриного тропонина С сердечной мышцы и пр. Например, этим обосновывается содержание дипептидов гипотензивной направленности в мясных цельнокусковых продуктах сухого посола. В исследованиях in vivo на SHR мышах показано, что гидролизаты продуктов обладают эффектом снижения систолического давления до 50 мм.рт.ст. в течение 6-8 часов после внутрижелудочного введения в количестве от 1 до 10 г/кг веса крыс [1].

Содержание в продуктах или сырье таких аминокислот как метионин, пролин, гистидин, триптофан, тирозин, фенилаланил и цистеин, может свидетельствовать о наличии антиоксидантных пептидов. Показано, что последовательности, обладающие антиоксидантными свойствами, высвобождаются при гидролизе говяжьих коллагена al, тропомиозина al, саркоплазматических белков печени, свиных миофибриллярных белков, куриного белка и говяжьей крови. В частности, выявлено, что сыровяленые свиные колбасы, в частности, испанская «Чоризо», кантонская колбаса и хорватской «Петровац», в водорастворимой фракции белков содержат множество антиоксидантных пептидов [5].

Таким образом, разработка биологически активных модулей на основе биокорригирующих пептидов из животного сырья путем, является весьма актуальным. quences with the antimicrobial activity, polypeptide of the cross-striated muscles (connectin) - peptides with the antithrombotic, antiamnesic, opioid, neuroprotective, immunomodulatory, antioxidant and hypotensive activities; beef, chicken and pork actin - sequences- inhibitors of dipeptidyl peptidase IV. In addition, collagen and elastin contain the sequences with specific corrective properties due to high content of functional amino acids - glycine and proline [4]. Nowadays, approximately 220 functional peptides consisting of 2-10 amino acid residues have been identified. Hypotensive peptides are the most studied. According to the mechanism of action, hypotensive peptides are divided into the correctors of endothelial precursor cells, renin-angiotensin system due to reduction of the renin concentration or inhibition of the angiotensin-converting enzyme (ACE) and activators of NO-synthase. Moreover, it was shown that hypotensive sequences are released during hydrolysis of the myosin heavy chain of chicken thigh and collagen, beef sarcoplasmic proteins, pork nebulin, myosin (heavy chain), actin, troponin $\mathrm{C}$ and titin, as well as beef, pork and chicken troponin $\mathrm{C}$ of the cardiac muscle and etc. For example, fermentation and autolysis stimulate enrichment of muscle dry-cured meat products by dipeptides with the hypotensive activity. In vivo studies on the SHR mice showed that intragastric administration of product hydrolysates in a dose of 1 to $10 \mathrm{~g} / \mathrm{kg}$ body weight reduced the systolic blood pressure to $50 \mathrm{~mm} \mathrm{Hg}$ during 6-8 hours [1].

The content of such amino acids as methionine, proline, histidine, tryptophan, tyrosine, phenylalanyl and cysteine in products or meat raw can indicate the presence of antioxidative peptides. Sequences with antioxidative properties were released arter hydrolysis of beef collagen $a 1$, tropomyosin a1, liver sarcoplasmic proteins, pork myofibrillar proteins, chicken protein and beef blood. In particular, it was revealed that raw air dried pork sausages such as Spanish Choriso, Canton sausage and Croatian Petrovac sausage contain many antioxidant peptides in water soluble fraction of proteins [5].

Therefore, development of biolactive modules on the basis of bio-corrective peptides from animal raw material is quite acute. 
Проведенными ранее исследованиями показано, что аорты Sus scrofa являются перспективным источником белково-пептидных веществ молекулярной массой (Мм) от 100 кДа до 10 кДа, обладающих гиполипидемической, антиоксидантной активностями, а также способствующих восстановлению функционирования эндотелиального слоя сосудов [6, 7].

Целью данного исследования являлось изучение возможности применения методов in vitro для изучения биологической активности среднемолекулярных и низкомолекулярных веществ, содержащихся в аорте Sus scrofa.

\section{Материалы и методы}

Объектами исследования являлись низкомолекулярные (молекулярная масса менее 5 кДа) и среднемолекулярные (молекулярная масса от 5 до 30 кДа) ультрафильтраты аорты Sus scrofa. Экстракт получали путем экстрагирования измельченных аорт в изотоническом физиологическом растворе (0,9\% раствор натрия хлорида) на лабораторной диспергирующей установке (Лаботекс, Россия) в течение 24 ч при 600 об/мин, температуре $(2-5){ }^{\circ} \mathrm{C}$, при соотношении сырье: экстрагент 1:5; отделение нерастворимого осадка проводили путем центрифугирования на центрифуге CM-6M (Elmi, Великобритания) в течение 8 мин при 3500 об/мин. Получение ультрафильтратов с веществами молекулярной массой менее 5 кДа (УФ <5кДа) и от 5 до 30 кДа (УФ5-30кДа) производили путем фракционирования экстракта на установке Vivaflow 200 (Sartorius, Германия) с использованием мембран из полисульфона с диаметром пор 30кДа и 5 кДа. Полученные ультрафильтраты хранили при температуре минус $(40)^{\circ} \mathrm{C}$. Концентрацию белка в экстрактах и ультрафильтратах определяли биуретовым методом на фотометре BioChem SA (HTI, США).

Исследование биологической активности полученных образцов проводили на эксплантатах тканей сердца $(n=40)$ и сосудов $(n=40) 10$-дневных куриных эмбрионов и эксплантатах тканей аорты $(\mathrm{n}=30)$ стареющих лабораторных крыс-самцов линии Wistar (450500 г). Куриные эмбрионы получали путем инкубирования яиц в условиях $\mathrm{CO}^{2}$ - инкубатора (Lamsystems, Россия) при $38,5^{\circ} \mathrm{C}$ в увлажненной атмосфере и концентрацией углекислого газа 5 \%. Выделение фрагментов тканей (эксплантатов) и все манипуляции проводили в условиях асептики в ламинарном боксе (Lamsystems, Россия).

Эксплантаты (около $1 \mathrm{~mm}^{3}$ ) помещали в чашки Петри с коллагеновым покрытием (Thermo Fisher Scientific, США), инкубировали 5-7 мин при $37^{\circ} \mathrm{C}$ для прикрепления эксплантатов, затем добавляли питательную среду с внесёнными исследуемыми образцами в концентрации 100 нг/мл. Питательная среда для эксплантатов тканей куриного эмбриона содержала 35 \% раствора Игла, 25 \% фетальной сыворотки телен-
Previous studies have shown that Sus scrofa aortas are source of proteins and peptides with molecular weight (Mw) of $100 \mathrm{kDa}$ to $10 \mathrm{kDa}$ with hypolipidemic and antioxidant activities, as well as stimulating of recovery of endothelial layer in blood vessels [6, 7].

The aim of the study was to evaluate the possibility of in vitro methods implementation for investigation of the biological activity of the medium-molecular-weight and lowmolecular-weight substances contained in Sus scrofa aorta.

\section{Materials and methods}

Objects were low-molecular-weight (less than $5 \mathrm{kDa}$, $\mathrm{Mw}$ ) and medium-molecular-weight (5-30 kDa, Mw) ultrafiltrates of Sus scrofa aorta. Minced aortas were extracted by isotonic physiological solution $(0.9 \% \mathrm{NaCl}$ solution) on a laboratory dispersing equipment (Labotex, Russia) for 24 hours at $600 \mathrm{rpm}$, temperature of $2-5^{\circ} \mathrm{C}$ and ratio of raw material:extractive agent 1:5. Insoluble residue was separated by centrifugation on a centrifuge CM-6M (Elmi, UK) for $8 \mathrm{~min}$ at $3500 \mathrm{rpm}$. The ultrafiltrates with molecular weight less than $5 \mathrm{kDa}(\mathrm{UF}<5 \mathrm{kDa})$ and 5 to $30 \mathrm{kDa}$ (UF 5-30 kDa) were obtained by fractionation on a Vivaflow 200 (Sartorius, Germany) using PES membranes with $30 \mathrm{kDa}$ and $5 \mathrm{kDa}$ pore diameters. Obtained ultrafiltrates were stored at a temperature of $-40^{\circ} \mathrm{C}$. A protein concentration in extract and ultrafiltrates was determined by biuret method on BioChem SA analyzer (HTI, USA).

The biological activity was studied on explants of the cardiac $(n=40)$ and vessel $(n=40)$ tissues of 10 -day old chicken embryos and on explants of the aortic tissues $(\mathrm{n}=30)$ of aging laboratory male Wistar rats (450-500 g). Chicken embryos were obtained by incubation of eggs in $\mathrm{CO}_{2}$ incubator (Lamsystems, Russia) at $38.5^{\circ} \mathrm{C}$ in wetted atmosphere and 5\% $\mathrm{CO}_{2}$ concentration. Isolation of tissue fragments (explants) and all manipulations were carried out in aseptic conditions in a laminar box (Lamsystems, Russia).

The explants (about $1 \mathrm{~mm}^{3}$ ) were transferred into Petri dishes coated with collagen (Thermo Fisher Scientific, USA) and incubated for $5-7 \mathrm{~min}$ at $37^{\circ} \mathrm{C}$ for explant adhesion. Then, a culture medium with samples was added in a concentration of $100 \mathrm{ng} / \mathrm{ml}$. The culture medium for the explants of the chicken embryo tissues contained 35\% of Eagle solution, $25 \%$ of fetal calf serum, $35 \%$ of Hanks' solution, $5 \%$ of chicken embryo extract, $0.6 \%$ of glucose, 
ка, 35 \% раствора Хенкса, 5 \% куриного эмбрионального экстракта, 0,6 \% глюкозы, 0,5 ед/мл инсулина, 100 ед/мл бензил - пенициллина, 2 мМ глютамина. Питательная среда для эксплантатов тканей крыс состояла из 35 \% среды Игла, 35 \% раствора Хенкса, $25 \%$ фетальной бычьей сыворотки и 5 \% куриного эмбрионального экстракта. Инкубированние эксплантатов проводили в условиях $\mathrm{CO}^{2}$ - инкубатора (Lamsystems, Россия) в течение 48 часов при $38,5^{\circ} \mathrm{C}$ в увлажненной атмосфере и концентрацией углекислого газа $5 \%$.

Анализ биологической активности проводили с использованием фазово-контрастного инвертируемого микроскопа (ЛОМО, Россия), путем определения индекса площади (ИП), который рассчитывали, как соотношение площади всего эксплантата, включая периферическую зону роста, к исходной площади эксплантата. За условную единицу площади принимали квадрат окуляр - сетки микроскопа (сторона квадрата при увеличении $3,5 \times 10$ равнялась 150 мкм). Значения ИП выражали в процентах, контрольное значение ИП принимали за 100 \% [8]. Контролем служили эксплантаты, инкубированные в питательной среде, без добавления образцов исследования

Для расчетов использовали программу STATISTICA 10, результаты представлены в виде «Взвешенное среднее значение \pm Стандартное отклонение» $(\mathrm{M} \pm \mathrm{m})$. Статистическая достоверность - однопараметрическим ANOVA тестом. В качестве значимого уровня выбрана вероятность 0.05 .

\section{Результаты и обсуждение}

Анализ эксплантатов тканей куриных эмбрионов и крыс через 24 часа после начала культивирования в питательной среде с добавлением исследуемых образцов, показал распластывание фрагментов тканей аорты и сердца на коллагеновой подложке и первичное выселение периферической зоны эксплантата.

Общеизвестно, что формирование периферической зоны эксплантатов зависит от пролиферативных, миграционных и адгезивных свойств различных типов клеток [9]. В данной работе учтен суммарный эффект этих процессов, выраженных в размерах формирующейся зоны выселяющихся клеток.

Через 48 часов культивирования эксплантатов куриных эмбрионов отмечены выраженные зоны центральная, представленная немигрирующими плотно расположенными клетками, и периферический монослой, формирующийся мигрирующими и пролиферирующими клетками. Выявлены отчетливые изменения роста клеток под влиянием исследуемых веществ белковой природы, предположительно показывающие направленность действия исследуемых образцов. При этом отмечено, что индексы площади эксплантатов тканей сердца и аорты куриного эмбриона при добавлении исследуемых образцов были различны. Добавление среднемолеку-
0.5 units/mL of insulin, 100 units $/ \mathrm{mL}$ of benzylpenicillin, $2 \mathrm{mM}$ of glutamine. The culture medium for rat tissues explants consisted of 35\% of Eagle solution, $35 \%$ of Hanks' solution, $25 \%$ of fetal bovine serum and $5 \%$ of chicken embryo extract. Incubation of the explants was carried out in $\mathrm{CO}_{2}$ incubator (Lamsystems, Russia) for 48 hours at $38.5^{\circ} \mathrm{C}$ in a wetted atmosphere and $5 \% \mathrm{CO}_{2}$ concentration.

An analysis of the biological activity was carried out on inverted phase contrast microscope (LOMO, Russia) by determining an area index (AI), which was calculated as a ratio of the area of the whole explant including the peripheral growth zone to the initial area of the explant. The square of the grid reticle of a microscope (a square side at magnification of $3.5 \times 10$ was equal to $150 \mu \mathrm{m}$ ) was taken as reference unit. The values of AI were calculated in percentages; the control value of AI was assumed to be $100 \%$ [8]. The explants incubated in the culture medium without adding the test samples were a control.

STATISTICA 10 program was used for calculation, the results were presented as weighted mean \pm standard deviation $(\mathrm{M} \pm \mathrm{m})$. Statistical significance was determined by one-way ANOVA-test. The probability value ( $p$-value) of 0.05 was chosen as a significance level.

\section{Results and discussions}

Explants of the chicken embryo and rat tissues wereanalyzed after 24 hours of cultivation in a culture medium with addition of the test samples. The spreading of aortic and cardiac tissues fragments on a collagen substrate was observed as well as peripheral zone primary expulsion of the explant.

Formation of explant peripheral zone depends on the proliferative, migratory and adhesive properties of different cell types [9]. Therefore the sum effect of these processes expressed in forming square zone of expulsed cells was taken into account.

After 48 hours two zones in cultivated chicken tissue explants were observed: the central zone was formed by non-migrating densely arranged cells and the peripheral monolayer was formed by migrating and proliferating cells. Test substances consisting of proteins and peptides enhanced cell growth, presumably, due to its tissue specificity. Moreover, it was noticed that area indices of cardiac and aortic tissues explants of chicken embryos with addition of the test samples were different. Addition of UF $5-30 \mathrm{kDa}$ in concentration of $100 \mathrm{ng} / \mathrm{ml}$ stimulated 
лярных ультрафильтратов экстракта аорты Sus scrofa в концентрации 100 нг/мл стимулировало рост эксплантатов сердца куриных эмбрионов на 31,6 \pm 5,4 \%, аорты - на 56,6 $\pm 5,2 \%,(p=0,05)$ соответственно. При добавлении в питательную среду низкомолекулярных фракций, наблюдалось достоверное вызывало повышение ИП эксплантатов на 28,6 $\pm 5,01 \%$ и $37,47 \pm 3,27 \%$, соответственно (Рисунок 1 ). the growth of tissue explants of chicken embryo heart by $31.6 \pm 5.4 \%$, while aorta - by $56.6 \pm 5.2 \%$, $(\mathrm{p} \leq 0.05)$. Addition of $\mathrm{UF}<5 \mathrm{kDa}$ caused a significant increase in $\mathrm{AI}$ of explants by $28.6 \pm 5.01 \%$ and $37.47 \pm 3.27 \%$, respectively (Fig. 1).

Addition of test samples to aortic tissues of aging rats

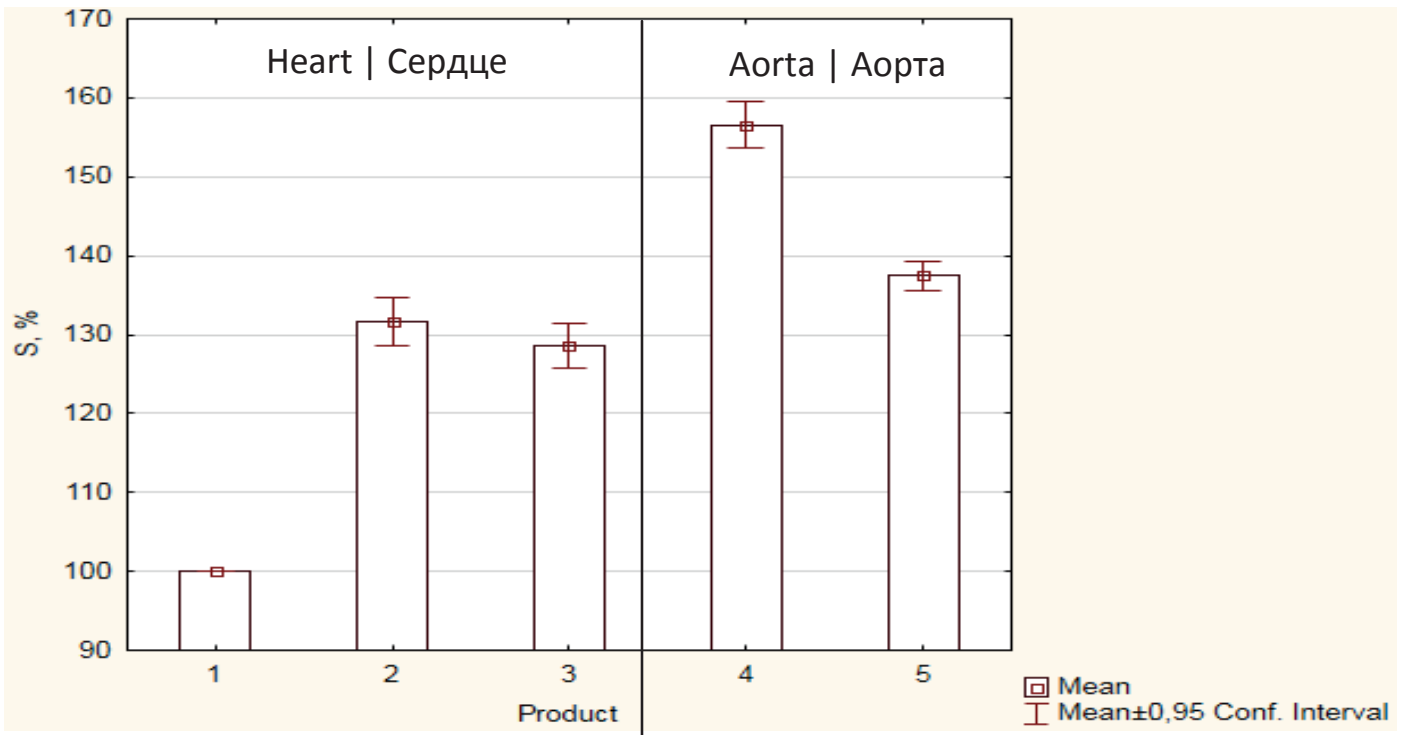

Figure 1. Influence of test samples in a concentration of $100 \mathrm{ng} / \mathrm{ml}$ on expulsed cells growth in cardiac and aortic tissues of chicken embryos. On the $\mathrm{x}$-axis: samples numbers; on the $\mathrm{x}$-axis : AI, \%. Legend: 1 - control; 2, 4 - UF 5-30 kDa; 3, 5 - UF $<5 \mathrm{kDa}$.

Рис. 1. Влияние исследуемых образцов в концентрации 100 нг/мл на рост выселяющихся клеток в зоне роста культуры ткани сердца м аорты куриного эмбриона. По оси х - наименование образцов; по оси у - ИП, \%. Условные обозначения: 1 - контроль; $2,4-$ среднемолекулярные ультрафильтраты (5-30 кДа); 3, 5 - низкомолекулярные ультрафильтраты (менее 5 кДа).

Исследования на фрагментах тканей аорты стареющих крыс показали противоположную динамику наибольшей биологической активностью обладали низкомолекулярные фракции, содержащие вещества молекулярной массой менее 5 кДа. Это выражалось в более интенсивной стимуляции роста монослоя клеток - ИП при добавлении низкомолекулярных ультрафильтратов увеличивался на $26,2 \pm 2,5 \%$, при добавлении среднемолекулярных - на 17,6 $\pm 3,96 \%$, по сравнению с контрольными значениями (Таблица 1).

Полученные данные свидетельствуют о возможности применения методов in vitro для изучения биологической активности белково-пептидных комплексов, выделенных из аорты Sus scrofa. При этом отмечено, что обнаруженная биологическая активность зависит от молекулярной массы веществ. Так, среднемолеку- showed opposite dynamic: the highest biological activity was observed in $\mathrm{UF}<5 \mathrm{kDa}$. $\mathrm{UF}<5 \mathrm{kDa}$ more intensively stimulated growth of cell monolayer compared to the control values. Addition of UF $<5 \mathrm{kDa}$ increased AI by $26.2 \pm 2.5 \%$ while UF $5-30 \mathrm{kDa}-$ by $17.6 \pm 3,96 \%$ (Table 1).

Revealed data confirmed the possibility of in vitro methods implementation for investigation of biological activity of protein-peptide complexes derived from Sus scro$f a$ aorta. Moreover, it was noticed that observed biological activity depended on molecular weight of substances. Thus, medium-molecular-weight fraction (5-30 kDa, Mw) stimulated the growth of aortas tissue explants of chicken embryo on $50 \%$ higher than the low-molecular-weight

Table 1. Influence of test samples on growth of aortic tissue explants of aging rats

Таблица 1. Влияние исследуемых образцов на рост эксплантатов тканей аорты стареющих крыс

\begin{tabular}{|l|c|c|c|}
\multicolumn{1}{|c|}{ Sample } & \multicolumn{3}{|c|}{ AI, \% | ИП, \% } \\
\hline \multicolumn{1}{|c|}{} & M (mean) | M (ср. знач.) & $\begin{array}{c}\text { m (standard deviation) } \\
\text { m (стнд. откл.) }\end{array}$ & $\begin{array}{c}\text { SE (standard error) | } \\
\text { SE (стнд. ошибка) }\end{array}$ \\
\hline UF 5-30 kDa | УФ 5-30 кДа & 117.600 & 3.96 & 1.294 \\
\hline UF < 5 kDa | УФ < 5 кДа & $126.200^{*}$ & 2.513 & 0.649 \\
\hline
\end{tabular}

* - significant difference from UF 5-30 kDa $(\mathrm{P}<0.05)$. | — достоверное отличие от УФ 5-30 кДа $(\mathrm{P}<0,05)$. 
лярная фракция (Мм 5-30 кДа) стимулировала рост эксплантатов тканей аорты куриных эмбрионов более чем на 50\% активнее, чем низкомолекулярная фракция (Мм менее 5 кДа). При этом выраженных эффектов на фрагменты сердца куриного эмбриона не выявлено. Отмечено, что низкомолекулярная фракция обладала более выраженным эффектом на эксплантаты тканей аорты стареющих крыс - ИП превышал значение эксплантатов, инкубируемых с добавлением среднемолекулярных фракций, до 30 \%. Стоит отметить, что при старении происходят различные изменения, характеризующиеся снижением биосинтеза белков, регуляторных пептидов в соответствующих органах и тканях, нарушения взаимодействия "регулятор-мишень» и прочее. Полученные данные свидетельствуют о возможности использования ультрафильтратов в качестве регуляторов гомеостаза, включая межклеточный сигналинг, что открывает возможности дальнейшего исследования выделенных веществ, их разделения и изучения молекулярно-биологического механизма действия.

\section{Выводы}

В результате исследования показана возможность применения методов in vitro для изучения биологической активности и направленности действия белковопептидных веществ, выделенных из аорты Sus scrofa.

Исследуемые образцы оказывали выраженное влияние на развитие и рост эксплантатов тканей куриных эмбрионов и стареющих крыс в зависимости от их молекулярной массы. Так, среднемолекулярные фракции, содержащие вещества массой 5-30 кДа, оказывают выраженный биологический эффект на эксплантаты аорты куриного эмбриона (увеличивая индекс площади эксплантатов на 56,6 + 5,2 \%, по сравнению с контрольными значениями). Низкомолекулярные фракции, содержащие вещества менее 5 кДа, напротив, оказывали более выраженное стимулирующее действие на эксплантаты аорты стареющих крыс - ИП превышал показатели среднемолекулярных фракций более чем на $30 \%$. fraction (less than $5 \mathrm{kDa}, \mathrm{Mw}$ ). However, both medium and low-molecular-weight fractions did not intensively influence on heart fragments of chicken embryo. It was observed that low-molecular-weight fraction significantly affected on aortas tissue explants of aging rat: AI was on $30 \%$ higher compared with medium-molecular-weight fraction. Aging is traditionally associated with different changes such as decrease in protein and regulatory peptides biosynthesis in corresponding organs and tissues, as well as with disorder in «regulator-target» interaction and others. Obtained data confirmed the possibility of ultrafiltrates application as regulators of homeostasis including intercellular signaling. Nevertheless, further research of isolated substances and its separation are nessesary for explanation of molecular biological mechanism of action.

\section{Conclusion}

Obtained result confirmed the possibility of in vitro methods implementation for investigation of biological activity and tissue specificity of protein-peptide substances derived from Sus scrofa aorta.

Test samples influenced on proliferation and growth of tissue explants of chicken embryos and aging rats. Observed effects depended on molecular weight of fractions. Thus, medium-molecular-weight fractions containing the substances with molecular weight of $5-30 \mathrm{kDa}$ predominantly stimulated the growth of aortas explants of chicken embryo (AI of explants increased by $56.6 \pm 5.2 \%$ compared with control values), while low-molecular-weight fractions containing the substances with molecular weight low than $5 \mathrm{kDa}$ more primarily stimulated the growth of aortic explants of aging rats: AI was more than $30 \%$ than in medium-molecular-weight fraction. 
БИБЛИОГРАФИЧЕСКИИ СПИСОК 1. Ahhmed A.M. A review of meat protein hydrolysates and hypertension / A.M. Ahhmed, M. Muguruma // Meat science. 2010. - № 86. - P. 110-118.

2. Lafarga T. Bioactive peptides from meat muscle and byproducts: generation, functionality and application as functional ingredients / T. Lafarga, M. Hayes // Meat science. - 2014. № 98. - P. 227-239.

3. Mine Y. Nutraceutical Science and Technology (Book 4). Nutraceutical Proteins and Peptides in Health and Disease / Y. Mine, F. Shahidi // USA: Taylor \& Francis Group, -2006. - P. 688.

4. Bauchart, C. Small peptides $(<5 \mathrm{kDa})$ found in ready-to-eat beef meat / C. Bauchart, D. Re mond, C. Chambon, P. Patureau Mirand, I. Savary-Auzeloux, C. Reyne`s, M. Morzel // Meat science. -2006 . - № 74. - P. 658-666.

5. Udenigwe C.C. Meat proteome as source of functional biopeptides / C.C. Udenigwe, A. Howard // Food Research International. - 2013. - № 54. - P. 1021-1032.

6. Чернуха И.М. Влияние тканеспецифичных биомолекул на дисфункцию эндотелия при атеросклерозе / И.М. Чернуха, А.В. Федулова, Е.А. Котенкова // Все о мясе. - 2016. - № 1. C. $46-49$.

7. Котенкова Е.А. Применение биотехнологических и протеомных методов при разработке продуктов питания гиполипидемического и вазопротекторного действия : автореферат Аис. ... кандидата технических наук : 05.18.04, 05.18.07 / Котенкова Е. А.; [Место защиты: Всерос. науч.-исслед. ин-т мясной пром-сти им. В.М. Горбатова]. - Москва, 2015. - С. 7.

8. Назаренко А.Б. Способ получения биологически активного комплекса и биологически активный белково-полипептиАный комплекс / А.Б. Назаренко, М.А. Соколов, И.Н. Жукова // Патент РФ 2428196 от 10.09.2011

9. Хавинсон В.Х. Тканеспецифическое действие пептидов в культуре тканей крыс разного возраста / В.Х. Хавинсон, В.В. Малинин, Н.И. Чалисова, Е.И. Григорьев // Успехи геронтологии - 2002. - Т. 3. - № 9. - С. 248-252.

\section{REFERENCES}

1. Ahhmed A.M. A review of meat protein hydrolysates and hypertension/ A.M. Ahhmed, M. Muguruma // Meat science. 2010. - № 86. - P. 110-118.

2. Lafarga T. Bioactive peptides from meat muscle and byproducts: generation, functionality and application as functional ingredients / T. Lafarga, M. Hayes // Meat science. - 2014. № 98. - P. 227-239.

3. Mine Y. Nutraceutical Science and Technology (Book 4). Nutraceutical Proteins and Peptides in Health and Disease / Y. Mine, F. Shahidi // USA: Taylor \& Francis Group, - 2006. - P. 688.

4. Bauchart, C. Small peptides ( $<5 \mathrm{kDa})$ found in ready-to-eat beef meat / C. Bauchart, D. Re' mond, C. Chambon, P. Patureau Mirand, I. Savary-Auzeloux, C. Reyne`s, M. Morzel // Meat science. - 2006. - № 74. - P. 658-666.

5. Udenigwe C.C. Meat proteome as source of functional biopeptides / C.C. Udenigwe, A. Howard // Food Research International. - 2013. - № 54. - P. 1021-1032.

6. Chernukha I.M. Effect of tissue specific biomolecules on endothelial dysfunction in atherosclerosis / I.M. Chernukha, L.V. Fedulova, E.A. Kotenkova // Vse o myase. - 2016. - № 1. P. 46-49.

7. Kotenkova E.A. Use of the biotechnological and proteomic methods in development of food products with hypolipidemic and vasoprotective action: author's abstract of the dissertation .. candidate of technical sciences: 05.18.04, 05.18.07 / Kotenkova E.A. [The venue of defense: The V.M. Gorbatov All-Russian Meat Research Institute]. - Moscow, 2015. - P. 27.

8. Nazarenko A.B. A method for obtaining a biologically active complex and biologically active protein-polypeptide complex / A.B. Nazarenko, M.A. Sokolov, I.N. Zhukova // RF Patent 2428196 of 10.09 .2011

9. Khavinson V.Kh. Tissue specific action of peptides in the tissue culture of rats of different ages / V.Kh. Khavinson, V.V. Malinin, N.I. Chalisova, E.I. Grigoriev// Uspekhi Gerontologii (Advances in Gerontology) - 2002. - Vol. 3. - № 9. - P. 248-252.

\section{СВЕДЕНИЯ ОБ АВТОРАХ}

Принадлежность к организации

Федулова Лилия Вячеславовна - кандидат технических наук, заведующий Экспериментальной клиники-лаборатории биологически активных веществ животного происхождения, Всероссийский научно-исследовательский институт мясной промышленности имени В.М. Горбатова,

109316, г. Москва, ул. Талалихина,26

Телефон: раб. 8-495-676-92-11

E-mail: fedulova@vniimp.ru

Кашинова Эльта Басанговна - научный сотрудник Экспериментальной клиники-лаборатории биологически активных веществ животного происхождения, Всероссийский научно-исследовательский институт мясной промышленности имени В.М. Горбатова, 109316, г. Москва, ул. Талалихина,26

Телефон: раб. 8-495-676-92-11

E-mail: vivarium@vniimp.ru

Котенкова Елена Александровна - кандидат технических наук, научный сотрудник Экспериментальной клиники-лаборатории биологически активных веществ животного происхождения, Всероссийский научно-исследовательский институт мясной промышленности имени В.М. Горбатова,

109316, г. Москва, ул. Талалихина,26

Телефон: раб. 8-495-676-92-11

E-mail: lazovlena92@yandex.ru

\section{Критерии авторства}

Авторы в равных долях имеют отношение к написанию рукописи и одинаково несут ответственность за плагиат.

Конфликт интересов

Авторы заявляют об отсутствии конфликта интересов.

Поступила 14.10.2016

\section{AUTOR INFORMATION} Affiliation

Fedulova Lilija - candidate of technical sciences, head of Experimental clinic - laboratory of biologically active substances of an animal origin, The V.M. Gorbatov All-Russian Meat Research Institute, 109316, Moscow, Talalikhina str., 26

Tel.: 8-495-676-92-11

E-mail: fedulova@vniimp.ru

Kashinova Elta - research scientist of Experimental clinic - laboratory of biologically active substances of an animal origin, The V.M.Gorbatov All-Russian Meat Research Institute,

109316, Moscow, Talalikhina str., 26

Tel.: 8-495-676-92-11

E-mail: vivarium@vniimp.ru

Kotenkova Elena - candidate of technical sciences, research scientist of Experimental clinic - laboratory of biologically active substances of an animal origin, The V.M.Gorbatov All-Russian Meat Research Institute,

109316, Moscow, Talalikhina str., 26

Tel.: 8-495-676-92-11

E-mail: lazovlena92@yandex.ru

\section{Contribution}

Authors equally contributed to the writing of the manuscript and are equally responsible for plagiarism.

\section{Conflict of interest}

The authors declares no conflict of interest.

Received 14.10.2016 